\title{
KONTEKS PENGGUNAAN BAHASA TABU SEBAGAI PENDIDIKAN ETIKA TUTUR DALAM MASYARAKAT PIDIE
}

\author{
Junaidi*,**Vera Wardani, \\ *Junaidi adalah Dosen FKIP Universitas Serambi Mekkah Banda Aceh \\ Email: junaidizainalarsyah@ @erambimekkah.ac.id \\ ** Vera Wardani adalah Dosen FKIP Universitas Jabal Ghafur Sigli \\ Email : verawardani5@gmail.com
}

\begin{abstract}
Abstrak
Tujuan penelitian ini untuk mendeskripsikan konteks penggunaan bahasa tabu dalam masyarakat Pidie. Jenis penelitian ini adalah penelitian lapangan (field research) dengan menggunakan pendekatan kualitatif. Metode yang digunakan metode deskriptif-analitis. Data penelitian ini adalah bahasa tabu berbentuk lisan dalam masyarakat Pidie. Sumber data penelitian ini adalah informan, yaitu masyarakat yang menetap di kabupaten Pidie, berjumlah 15 orang yang berdomisili pada sebelas gampông dalam kecamatan yang ada di kabupaten Pidie. Pengumpulan data dilakukan dengan menggunakan teknik wawancara terstruktur yang didukung oleh teknik pancingan. Teknik analisis data yang digunakan adalah teknik analisis kualitatif dengan tahapan-tahapan, menyeleksi data, mendeskripsikan keseluruhan data, mengelompokkan data berdsarkan konteks penggunaannya, dan menganalisis data untuk ditarik simpulan. Hasil penelitian ditemukan bahwa konteks penggunaan bahasa tabu dalam masyarakat Pidie terjadi pada beberapa konteks, yang meliputi konteks (1) pembicara dan pendengar pembicaraan, (2) latar atau tempat pembicaraan, (3) waktu pembicaraan, (4) topik atau peristiwa yang dibicarakan, (5) suasana atau situasi pembicaraan, dan (6) tujuan atau maksud pembicaraan. Masyarakat Pidie kadang-kadang menggunakan bentuk eufemisme untuk menggantikan bahasa tabu kata-kata. Namun, tidak ada bentuk penyulihan kata apapun untuk menggantikan bahasa tabu sumpah serapah, selain penutur harus diam.
\end{abstract}

\section{Kata kunci: Bahasa tabu, Pendidikan dan Etika}

\section{PENDAHULUAN}

Masyarakat Pidie secara umum menggunakan bahasa Aceh sebagai bahasa ibu. Dalam bertutur, masyarakat Pidie sama halnya dengan masyarakat Aceh lainnya; memiliki prinsip kesantunan berbahasa dengan mitra tutur. Hal ini sejalan dengan pendapat Allan (dalam Rahardi, 2005:52) yang menyatakan bahwa agar proses komunikasi penutur dan mitra tutur dapat berjalan dengan baik dan lancar, antara penutur dan mitra tutur harus saling mengedepankan azas kerja sama yang baik. Lebih dari itu, ia berpendapat bahwa kerja sama yang baik itu salah satunya dapat dilakukan dengan adanya kesantunan berbahasa terhadap mitra tutur. 


\section{Junaidi dan Vera Wardani, Konteks Penggunaan Bahasa Tabu .......}

Salah satu hal yang sangat diperhatikan masyarakat Pidie adalah menghindari setiap larangan/pantangan dalam bertutur. Adanya larangan dan pantangan dalam bertutur disebabkan oleh kebudayaan dan kepercayaan yang mereka yakini. Tidak semua kalimat dapat dituturkan dalam konteks yang berbeda. Kadangkala dalam konteks tertentu suatu tuturan dapat diucapkan; tidak menyinggung perasaan lawan tutur, tetapi pada konteks yang lain menjadi larangan atau pantangan karena dapat menyinggung perasaan orang lain atau diyakini akan membawa petaka. Larangan dan pantangan ini disebut sebagai norma dan budaya yang sudah diyakini secara turun-temurun.

Kenyataan ini menunjukkan bahwa bahasa dan budaya merupakan dua hal yang saling mempengaruhi satu sama lain, tidak terkecuali dalam masyarakat Pidie. Bahasa yang digunakan oleh masyarakat Pidie dipengaruhi oleh budaya dan pola pikir masyarakat Pidie. Hal ini sejalan dengan pendapat Chaer dan Leonie (2010:162) yang menyebutkan bahwa bahasa adalah bahagiaan dari kebudayaan. Bahasa dan budaya merupakan dua sistem yang melekat pada manusia yang saling memengaruhi satu sama lain.

Budaya masyarakat dipengaruhi oleh berbagai faktor, salah satunya adalah faktor geografis (Ohoiwutun, 2007:50). Begitu juga halnya dengan masyarakat Pidie. Perbedaan letak geografis dan profesi masyarakat Pidie menyebabkan pola pikir dan kebudayaan masyarakat yang berbeda pula. Perbedaan itu mencakup kepercayaan dan norma-norma dalam kesantunan berbahasa. Dalam masyarakat yang berprofesi sebagai petani, ada kalimat-kalimat tertentu yang dilarang tuturannya ketika berada di sawah, tetapi larangan ini tidak berlaku bagi masyarakat yang berprofesi non-petani dan begitu juga sebaliknya.

Misalnya, seorang petani ketika menjenguk tanaman padinya yang sedang diserang hama tikus tidak boleh mengucapkan kalimat "Ka kap laju beu abéh padé lôn. Kutuba ngen racôn barô kateupeu droe" (Makan terus padi saya. Nanti diracun baru tahu rasa). Memang, sepintas lalu kalimat tersebut terlihat seperti biasa dan lazim didengarkan. Secara kebahasaan penggunaan kalimat tersebut juga sudah sesuai dan memiliki makna yang jelas. Namun, bagi masyarakat Pidie kalimat seperti di atas tidak boleh diucapkan ketika petani berada di sawahnya yang sedang diserang hama tikus. Masyarakat Pidie percaya bahwa jika kalimat seperti itu diucapkan di sawahnya, tikus dapat mendengarnya, sakit hati, lalu serangan hama tikus akan bertambah parah.

Oleh sebab itu, penelitian mengenai konteks penggunaan bahasa tabu dalam masyarakat Pidie perlu dilakukan untuk menjawab sebuah masalah yang menjadi tanda tanya selama ini. Adapun yang menjadi masalah dalam penelitian ini adalah pada konteks bagaimana sajakah bahasa tabu dalam masyarakat Pidie digunakan? Penelitian ini 
dilakukan guna menjawab sebuah tujuan yakni mendeskripsikan konteks penggunaan bahasa tabu dalam masyarakat Pidie.

\section{Bahasa Tabu}

Kata tabu (taboo) pertama kali digunakan oleh Kapten James Cook dalam pelayarannya yang ketiga mengelilingi dunia di Tonga, Kepulauan Polinesia pada tahun 1977. Konsep dasar tabu sampai sekarang tidak berubah, yaitu "larangan". Namun perubahan yang terjadi pada tabu adalah subtansi, sumber, dan jenis sanksinya (Laksana dalam Sutarman, 2013:13).

Konsep "tabu" pada sisi lain sama dengan konsep "magi", yaitu sebuah kata dengan kekuatan untuk mempengaruhi peristiwa. Keyakinan terhadap hal-hal tabu banyak ditemukan dalam masyarakat di Nusantara pada zaman dahulu maupun masyarakat sekarang. Sebagaimana telah dijelaskan pada definisi tabu sebelumnya, hal tabu bisa menyangkut perbuatan maupun perkataan. Kajian pada penelitian ini lebih menyangkut pada masalah tabu bahasa, yaitu bentuk tabu yang berasal dari ucapan atau perkataan.

Selajutnya Freud (dalam Ohoiwutun, 2007:14) menyatakan awalnya kata tabu mengacu pada hal-hal atau benda suci yang tidak dapat dibicarakan atau disentuh. Ketika Cook datang ke pulau di Pasifik Selatan (Polinesia), ia mengamati banyak fenomena sosial yang aneh. Sebagai contoh ada beberapa objek hanya dapat digunakan oleh pemimpin mereka atau hanya oleh Tuhan, beberapa benda lainnya hanya dapat digunakan oleh masyarakat umum, dan yang lainnya hanya dapat digunakan untuk tujuan khusus atau tertentu. Masyarakat setempat menyebut fenomena ini sebagai tabu.

Istilah tabu terus berkembang sejalan dengan penemuan-penemuan ilmiah yang dikemukakan para ahli. Tabu bukan lagi hanya sebagai perkataan mengenai hal-hal yang menyangkut ketakutan terhadap roh-roh gaib, melainkan juga berhubungan dengan sopan santun dan tata pergaulan sosial. Penghindaran atau pelarangan menyebutkan kata, frasa, dan lainnya atau memperbincangkan topik yang membuat orang lain tidak nyaman juga merupakan bagian dari tabu bahasa. Mempertimbangkan kesopanan dan kesantunan adalah pokok tabu bahasa. Kata-kata di luar koridor kesopansantunan terlarang untuk diucapkan atau digunakan.

Orang yang tidak ingin dianggap "tidak sopan" akan menghindarkan penggunaan kata-kata tertentu. Dalam masyarakat Indonesia, terutama dalam bahasa daerah, sering wanita lebih banyak menghindari penggunaan kata-kata yang berhubungan dengan alat- 


\section{Junaidi dan Vera Wardani, Konteks Penggunaan Bahasa Tabu .......}

alat kelamin atau kata-kata 'kotor' yang lain. Kata-kata ini seolah-olah ditabukan oleh kaum wanita, atau seolah-olah menjadi monopoli kaum pria (Sumarsono dan Paina, 2004:107).

Berdasarkan beberapa pendapat di atas dapat disimpulkan bahwa tabu bahasa adalah larangan untuk menggunakan kata-kata tertentu karena dianggap dapat mendatangkan malapetaka, melanggar etika sopan santun, mencemarkan nama, dan mendapat amarah dari manusia dan Tuhan. Seseorang yang telah melakukan tabu bahasa biasanya akan merasakan perasaan yang tidak tenang akibat ucapannya. Di samping itu, pelanggaran tabu bahasa akan menyebabkan relasi antara si pelanggar dan masyarakat sekitarnya akan menjadi renggang dan bisa saja si pelanggar akan terkucilkan.

\section{Konteks}

Arti konteks dalam KBBI (2008:728) adalah (1) bagian suatu uraian atau kalimat yang dapat mendukung atau menambah kejelasan makna; (2) situasi yang ada hubungannya dengan suatu kejadian. Adapun Kridalaksana (2008:134) menyatakan bahwa konteks adalah (1) aspek-aspek lingkungan fisik atau sosial yang kait mengait dengan ujaran tertentu, (2) pengetahuan yang sama-sama memiliki pembicara dan pendengar sehingga pendengar paham apa yang dimaksud pembicara.

Konteks adalah seperangkat asumsi yang dibangun secara psikologis oleh penutur dan pendengar tentang dunia. Konteks tidak hanya terbatas pada ujaran saat ini dan ujaran sebelumnya, tetapi menyangkut semua yang dapat terlibat dalam interpretasi, seperti harapan masa depan, hipotesis ilmiah, kepercayaan terhadap keagamaan, kenangan lucu, asumsi tentang kebudayaan (faktor sosial, norma sosial, dan sebagainya), dan kepercayaan terhadap penutur dan pendengar. Konteks mempengaruhi interpretasi penutur dan pendengar terhadap ujaran (wacana).

Secara garis besar, konteks terdiri atas dua macam, yaitu konteks situasi dan konteks suasana. 1) Konteks Situasi, menurut Halliday dan Hasan (1985:15) mengatakan yang dimaksud dengan konteks situasi adalah lingkungan langsung tempat teks itu benarbenar berfungsi. Atau dengan kata lain, kontek situasi adalah keseluruhan lingkungan, baik lingkungan tutur (verbal) maupun lingkungan tempat teks itu diproduksi (diucapkan atau ditulis).

Lebih lanjut, dalam pandangan Halliday dan Hasan (1985:16), konteks situasi terdiri dari (1) medan wacana, (2) pelibat wacana, dan (3) modus/sarana wacana. Medan wacana merujuk pada aktivitas sosial yang sedang terjadi atau apa yang sesungguhnya disibukkan oleh para pelibat. Pelibat wacana merujuk pada orang-orang yang mengambil 
bagian, sifat para pelibat, kedudukan dan peran mereka, jenis-jenis hubungan peranan apa yang terdapat di antara para pelibat. Sarana wacana merujuk pada bagian bahasa yang sedang dimainkan dalam situasi, termasuk saluran yang dipilih, apakah lisan atau tulisan.

Adapun Hymes (dalam Brown dan Yule, 1983:38) memberi penjelasan lebih rinci mengenai ciri-ciri konteks yang relevan dalam konteks situasi. Konteks dan situasi berikut adalah pembicara/penulis (addressor), pendengar/pembaca (addresse), topik pembicaraan (topic), saluran (channel), kode (code), bentuk pesan (message form), peristiwa (event), dan tempat/waktu (setting).

Selanjutnya Hymes (dalam Moeliono, 1991:23) merumuskan ihwal faktor-faktor penentu dalam peristiwa tutur dalam konteks situasi yang tidak jauh berbeda dengan penjelasan sebelumnya, melalui akronim SPEAKING. Tiap-tiap fonem mewakili faktor penentu yang dimaksudkan.

(S) Setting and scene, yaitu latar dan suasana. Latar (setting) lebih bersifat fisik, yang meliputi tempat dan waktu terjadinya tuturan. Sementara scene adalah latar psikis yang lebih mengacu pada suasana psikologis yang menyertai tuturan.

(P) Participants, peserta tuturan, yaitu orang-orang yang terlibat dalam percakapan, baik langsung maupun tidak langsung. Hal-hal yang berkaitan dengan partisipan, seperti usia, pendidikan, latar sosial, dan sebagainya juga menjadi perhatian.

(E) Ends, hasil, yaitu hasil atau tanggapan dari suatu pembicaraan yang memang diharapkan oleh penutur (ends as outcomes), dan tujuan akhir pembicaraan itu sendiri (ends in view goals).

(A) Act sequence, pesan/amanat, terdiri dari bentuk pesan (message form) dan isi pesan (message content).

(K) Key, meliputi cara, nada, sikap, atau semangat dalam percakapan. Semangat percakapan, misalnya: serius, santai, akrab, dan sebagainya.

(I) Instrumentalities atau sarana, yaitu sarana percakapan. Maksudnya dengan media apa percakapan tersebut disampaikan. Misalnya: dengan cara lisan, tertulis, surat, radio, dan sebagainya.

(N) Norms, menunjuk pada norma atau aturan yang membatasi percakapan. Misalnya, apa yang boleh dibicarakan dan tidak, bagaimana cara membicarakannya: halus, kasar, terbuka, dan sebagainya.

(G) Genres atau jenis, yaitu jenis atau bentuk wacana. Hal ini langsung menunjuk pada jenis wacana yang disampaikan. Misalnya: telepon, koran, puisi, ceramah, dan sebagainya. 


\section{Junaidi dan Vera Wardani, Konteks Penggunaan Bahasa Tabu .......}

Sedangkan Konteks Pengetahuan merupakan teori tindak tutur dan pragmatik memandang konteks dalam istilah pengetahuan, yaitu apa yang mungkin bisa diketahui oleh antara si pembicara dengan mitra tutur dan bagaimana pengetahuan tersebut membimbing/menunjukkan penggunaan bahasa dan interpretasi tuturannya (Schiffirin (1994:549). Artinya ketika pembicara dan mitra tutur memiliki kesamaan pengetahuan akan apa yang dibicarakan atau dapat juga disebut common ground, maka kesalahpahaman atau ketidaktepatan interpretasi tidak akan terjadi.

\section{METODE PENELITIAN}

Penelitian ini menggunakan pendekatan kualitatif. Pendekatan kualitatif dianggap sangat cocok digunakan karena penelitian ini bertujuan untuk mendeskripsikan, menganalisis, dan menafsirkan bentuk bahasa tabu dalam tuturan masyarakat Pidie.

Jenis penelitian ini adalah penelitian lapangan (field research). Menurut Hasan (2002:11), penelitian lapangan (field research) merupakan penelitian yang dilakukan di kancah atau medan terjadinya gejala. Adapun gejala yang dimaksud konteks penggunaan bahasa tabu dalam masyarakat Pidie.

Dalam penelitian, objeklah yang menentukan metode yang akan digunakan. Objek penelitian ini adalah bahasa tabu dalam masyarakat Pidie. Bahasa tabu dimaksud dideskripsikan dengan penekanan penganalisisan terhadap konteksnya. Dengan demikian penelitian ini menggunakan metode deskriptif-analitis.

Sumber data penelitian ini adalah informan. Informan yang peneliti maksud adalah masyarakat Pidie yang berasal dari beragam profesi, berjumlah 15 orang yang berdomisili pada sebelas gampông dalam kecamatan yang ada di kabupaten Pidie. Adapun yang menjadi data dalam penelitian ini adalah bahasa tabu berbentuk lisan dalam masyarakat Pidie yang sudah didapatkan dari informan.

\section{Teknik Pengumpulan Data}

Teknik pengumpulan data penelitian ini dengan menggunakan teknik wawancara. Wawancara yaitu tanya jawab sambil bertatap muka antara peneliti dan informan (Nazir, 2005:193). Wawancara dalam penelitian ini adalah wawancara terstruktur dengan menggunakan alat perekam. Wawancara terstruktur yaitu wawancara yang berpedoman pada pertanyaan yang sudah disiapkan dan tersusun secara sistematis.

Dalam pelaksanaanya, proses wawancara untuk memperoleh data penelitian juga didukung oleh teknik pancingan. Dengan teknik teknik pancingan, peneliti berusaha 
memancing informan dengan topik pembicaraan mengenai objek penelitian, guna memunculkan calon data sambil merekam pembicaraan. Hal tersebut sejalan dengan pendapat Samarin (1988:162) yang menyatakan bahwa teknik pancingan dilakukan oleh seorang peneliti untuk memperoleh data secara mendalam dalam jumlah fakta yang banyak untuk mendukung peneliti dalam menganalisis data.

\section{Teknik Analisis Data}

Teknik analisis data yang digunakan dalam penelitian ini adalah teknik analisis kualitatif dengan tahapan-tahapan (1) Menyeleksi data untuk memilih data yang benarbenar valid, (2) mendeskripsikan keseluruhan data bahasa tabu yang sudah benar-benar valid, (3) engelompokkan data bahasa tabu dalam masyarakat Pidie berdasarkan konteksnya, dan (4) melakukan penganalisisan data untuk ditarik simpulan.

\section{HASIL PENELITIAN DAN PEMBAHASAN}

Setelah dilakukan penganalisisan data diketahui bahwa konteks penggunaan bahasa tabu dalam masyarakat Pidie terjadi pada beberapa konteks berikut.

\section{Pembicara dan Pendengar Pembicaraan}

Pembicara dan pendengar merupakan orang yang terlibat dalam suatu peristiwa tutur. Komunikasi antarsesama akan dapat terjalin apabila adanya kedua pelaku peristiwa tutur tersebut. Begitu juga mengenai penggunaan bahasa tabu dalam masyarakat Pidie, seseorang tidak boleh dengan sembarangan mengucapkan kata-kata atau kalimat tertentu dalam konteks ini.

(a) Usia pembicara atau pendengar

(1) Nyan a lôn. (Itu kakak saya)

Penggunaan kata $a$ pada ujaran (1) ditabukan pengucapannya karena seorang adik tidak boleh menyebut kakaknya dengan sebutan $a$ karena dianggap tidak memiliki rasa hormat dan tidak beretika. Ujaran yang lebih halus dan sangat terhormat mengenai penyebutan nama kakak dalam masyarakat Pidie adalah menggantikan kata $a$ menjadi kak, cuda/cupo.

(b) Jabatan pembicara atau pendengar

(2) Jih lamiet bak rumoh lôn. (Dia babu di rumah saya) 


\section{Junaidi dan Vera Wardani, Konteks Penggunaan Bahasa Tabu .......}

Penggunaan kata lamiet pada ujaran (2) di atas dianggap tabu karena kata lamiet terkesan sangat hina kedudukannya dalam masyarakat Aceh, khususnya masyarakat Pidie. Untuk menggantikan ujaran yang halus dan sopan pada kalimat tersebut, kata lamiet dapat digantikan dengan bentuk yang cenderung lebih halus dan sopan yaitu peumbantu.

\section{Latar atau Tempat Pembicaraan}

Latar atau tempat pembicaraan mengacu pada tempat dimana terjadinya pembicaraan tersebut. Konteks penggunaan bahasa tabu karena latar atau tempat terjadinya pembicaraan dalam masyarakat Pidie terjadi pada konteks berikut ini.

(a) Di hutan

(3) Lam uteun nyoe na gajah. (Di hutan ini ada gajah)

Penyebutan langsung kata gajah pada ujaran (3) ditabukan penggunaanya oleh seseorang, apabila orang tersebut sedang berada di hutan atau di tengah rimba. Bagi masyarakat Pidie, menyebut setiap nama binatang buas dengan semena-mena, di antaranya seperti nama kedua binatang tersebut di hutan adalah hal yang dilarang, karena mereka percaya binatang-binatang buas yang disebut namanya itu akan datang dan ditakuti akan menyerang orang yang menyebutkannya. Bentuk eufemisme atau penghalusan yang digunakan untuk menghindari penyebutan langsung nama binatang ketika di hutan adalah kata gajah diganti dengan sebutan teungku rayek 'teungku besar' atau po meurah 'si murah hati'.

(b) Di sawah atau di kebun

(4) Tikôh paléh kabéh kapajôh padé lôn. (Tikus celaka habis semua kamu makan padi saya)

Penyebutan secara langsung kata tikôh pada ujaran (4) di atas merupakan hal yang ditabukan karena penyebutan tikôh pada konteks ini ditakuti akan membawa alamat yang tidak baik terhadap tanaman mereka seperti, padi atau palawija yang sedang ditanami. Petani di Pidie percaya, tikus adalah salah satu binatang yang disakralkan dan memiliki insting dendam yang kuat terhadap siapa saja yang mencaci atau mengganngunya. Oleh sebab itu, apabila seorang petani sedang melihat tanamannya diganggu oleh tikus, petani tersebut hendaknya menyemangati atau memohon pada binatang itu agar tidak mengganggu tanaman mereka lagi. Misalnya, seorang petani akan menyemangati dengan ucapan, “Kasép nyoe nyakti meutuah” (Sudah cukup wahai 'tikus' yang baik hati).

(c) Di laut atau di tempat berair 
(5) Sang na keutuka lam laôt nyoe.(Sepertinya ada keutuka di laut ini)

Pada ujaran (5), penggunaan kata keutuka dilarang pengucapannya apabila sedang berada di laut, khususnya di bibir pantai, seperti saat menjaring ikan atau mandimandi. Masyarakat Pidie, pada konteks ini takut menyebut-nyebut nama binatang laut itu, karena mereka percaya ujaran seperti itu akan mengundang binatang yang ditakuti tersebut dan bnatang itu diyakini akan menyerang mereka.

(d) Di pasar atau arena jual beli

(6) Meu-ureung tan, kacok katet keudè-keudè keudéh. (Tidak ada pembeli pun, bakar saja kedai-kedainya)

Seorang pedagang dilarang mengucapkan ujaran di atas karena dipercaya akan menghadirkan kemalangan terhadap mereka. Pedagang takut tempat mereka berjualan akan terkena musibah, seperti terbakar dan lain-lain.

\section{Waktu Pembicaran}

Waktu adalah seluruh rangkaian saat ketika proses, perbuatan, atau keadaan berada atau berlangsung. Dengan demikian, waktu pembicaraan adalah kapan terjadinya suatu pembicaraan.

(a) Pagi hari

(7) Neubi meu'utang saka si kilo.(Tolong dihutangkan gula satu kilo)

Ujaran di atas pantang diujarkan seorang pembeli terhadap penjual. Oleh sebab itu, jika seorang pembeli ingin berhutang, hendaknya maksud tersebut ditunaikan setelah melewati pagi hari saja, atau minimal pedagang yang dituju itu sudah mulai laris dagangannya. Masyarakat Pidie melarang hal tersebut karena mereka percaya dapat membawa sial terhadap pedagang, bisa jadi barang dagangan si pedagang tidak begitu laris nantinya.

(b) Malam hari

(8) Neubi sira bacut. (Tolong kasih garam sedikit)

Penggunaan secara langsung kata sira pada ujaran di atas pada waktu malam hari ditabukan penggunaannya dalam masyarakat Pidie. Hal tersebut dipercaya oleh mereka akan membawa alamat yang tidak baik terhadapnya. Oleh sebab itu, penggunaan kata sira dalam segala bentuk ujaran harus disulingkan dalam bentuk eufemisme lain jika pada konteks malam hari. Kata sira harus disebut peumasén 'mengasinkan' sambil 


\section{Junaidi dan Vera Wardani, Konteks Penggunaan Bahasa Tabu .......}

menunjuk ke arah barang yang dimaksud. Selain itu, segala ucapan yang berhubungan dengan makhluk halus juga harus dihindari pengucapannya pada malam hari. Hal ini dimaksud agar segala bentuk gangguan yang dapat menghadirkan ketakutan terhadap mereka terjauhkan.

\section{Topik atau Peristiwa yang Dibicarakan}

Mengenai topik atau peristiwa pembicaraan, dalam masyarakat Pidie ada dua konteks berlakunya bahasa tabu mengenai topik atau peristiwa yang dibicarakan.

(a) Hal atau benda yang disucikan/disakralkan

(9) Neubloe Alquran saboh beh! (Belikan Alquran satu ya!)

Penggunaan kata bloe pada ujaran di atas ditabukan karena takut berdosa karena merendahkan derajat kitab suci Alquran. Sebagaimana diketahui Alquran dalam Islam tidak boleh disamai dengan benda lainnya. Untuk mendapatkan Alquran, meskipun dengan cara mengeluarkan uang, seseorang harus mengubah ucapannya seperti, “Neuhadiah Alquran saboh beh!” (Hadiahkan Alquran satu ya!).

(b) Pekerjaan atau aktivitas tertentu

(10) Siap that lagoe, ho meujak nyan? (Siap sekali ya, mau ke mana itu?)

Ujaran (10) pada konteks percakapan sehari-hari dianggap biasa saja dan tidak menjadi masalah. Namun, jika ucapan tersebut diucapkan atau ditujukan terhadap orang yang akan berburu atau sedang berburu akan menjadi tabu dan dilarang. Masyarakat Pidie percaya ujaran tersebut akan membawa dampak sial terhadap pemburu yang akan berburu atau sedang berburu. Mereka meyakini pemburu tidak akan mendapatkan satu pun buruannya karena pengaruh ucapan itu.

\section{Suasana atau Situasi Pembicaraan}

Suasana atau situasi pembicaraan adalah merujuk bagaimana pada situasi atau suasana pembicara dan pendengar ketika berkomunikasi.

(a) Serius/marah

(11)Lagèe eungkong droekeuh. (Seperti beruk kamu ini)

Kalimat ujaran di atas ditabukan pengucapannya apabila seseorang berbicara pada situasi serius karena ujaran tersebut dapat menyakiti perasaan pendengar atau lawan 
bicara. Namun, pada konteks bercanda ujaran demikian justru dianggap biasa saja dan tidak dianggap tabu, selama penutur dan mitra tutur memiliki relasi yang sangat akrab.

(b) Bercanda

(12) Ma kah keuh. (Ibu kamu itu)

Penyebutan nama orang tua dalam ujaran (12) di atas dilarang, karena bagi masyarakat Pidie membawa-bawa nama orang tua dalam suatu perkara sepele tidak baik. Orang yang merasa nama orang tuanya dibawa dalam hal candaan akan menjadi marah dan sakit hati. Oleh sebab itu, candaan dengan membawa-bawa nama orang tua seperti itu sangat dilarang.

(c) Tegang dan takut

Perasaan tegang atau takut terkadang akan datang jika seseorang sudah berhadapan dengan hal yang ditakutinya. Oleh sebab itu, masyarakat Pidie akan menabukan ujaran-ujaran terhadap hal yang ditakutinya apabila mereka berhadapan dengan hal yang ditakuti itu.

(13) Hoi, unoe kleueng tak!

(Hei, lebah disambar elang!)

Dalam ujaran sehari-hari, ujaran (13) di atas dianggap biasa. Namun, ujaran tersebut akan ditabukan pengucapannya ketika seseorang melihat lebah yang jumlahnya banyak sedang berkumpul atau berterbangan. Masyarakat Pidie takut dan percaya, ujaran demikian akan membuat makhluk tersebut menjadi marah dan menyerang mereka yang mengucapkan perkataan seperti itu.

(d) Gembira/bereuforia

(14) Udu jai that eungkôt! (Wah Banyak sekali ikannya!)

Penggunaan kata jai that pada ujaran (14) di atas dianggap tabu dalam masyarakat Pidie apabila dilontarkan pada momen-momen gembira. Misalnya, mereka yang sedang mencari ikan atau benda buruan lainnya. Apabila benda buruannya banyak didapat atau ditemukan, mereka tidak boleh terlalu bereuforia dengan mengatakan, "Jai that eungkôt" (Banyak sekali ikan), "Jai that rôh” (Banyak sekali didapat), dan lain-lain. Masyarakat Pidie percaya, ujaran-ujaran demikian akan membawa sial.

\section{Tujuan atau Maksud Pembicaraan}

Pemilihan kata yang tepat untuk menyatakan suatu maksud dalam berkomunikasi merupakan salah satu cara agar terjalinnya komunikasi yang baik. Sebaliknya, 


\section{Junaidi dan Vera Wardani, Konteks Penggunaan Bahasa Tabu .......}

penggunaan kata yang tidak sesuai dengan konteksnya justru akan mendapatkan reaksi negatif dari lawan bicara. Oleh sebab itu, agar tujuan dan maksud komunikasi selalu terjalin antarsesama, masyarakat Pidie dalam konteks ujarannya akan menghindari penggunaan kata-kata-kata yang dianggap tabu dan cenderung mengundang reaksi negatif tersebut.

(a) Penawaran

(15) Hanjeut lôn bri barangnyoe, pangkai dumnoe. (Tidak bisa saya kasih barang ini, modalnya segini)

Ujaran (15) di atas adalah ujaran yang sering diucapkan oleh pedagang kepada pembeli ketika mengelak untuk memberikan dagangannya kepada pembeli dalam konteks penawaran. Ujaran tersebut sangat ditabukan dalam masyarakat Pidie karena ujaran demikian dianggap dapat menjerumuskan ke arah dosa. Sebab, belum tentu modal yang dikatakan pedagang itu ada benarnya. Indikasi kebohongan yang muncul akan menimbulkan dosa terhadap pedagang. Oleh sebab itu, seorang pedagang hendaknya tidak perlu mengatakan kepada pembeli tentang modal terhadap barang yang akan dijualnya itu.

(b) Perintah

(16) Nyan, ka jeuh'ak beu abéh ie nyan beh! (Itu, kamu minum sampai habis air itu ya!)

Penggunaan kata jeuh'ak pada ujaran di atas ditabukan penggunaannya dalam masyarakat Pidie karena kedua kata tersebut lebih tepat untuk perilaku binatang bukan untuk manusia. Seharusnya, pada konteks ini agar ujaran tersebut tidak lagi menjadi tabu, kata yang bergaris miring di atas dapat digantikan dengan kata jép 'minum'.

(c) Bersimpati atau berempati

(17) Udu, sayang teuh manok nyan ka geusie. (Aduh, sayang sekali ayam itu sudah disembelih)

Bersimpati atau berempati terhadap hewan/unggas yang akan disembelih untuk dikonsumsikan dilarang dalam masyarakat Pidie. Sebab, hewan/unggas yang akan dikonsumsi hendaknya diikhlaskan untuk disembelih agar menjadi halal untuk dikonsumsi, bukan malah menyatakan sayang. Sebab, ujaran demikian dapat menjadikan daging hewan/unggas yang halal dikonsumsi itu menjadi sesuatu yang haram.

(d) Memuji 
(18) Omin tumbôn that aneuk manyak nyoe. (Wah gemuk sekali anak ini ya)

Kalimat pujian pada ujaran di atas bertujuan untuk memuji tentang kesehatan seorang bayi. Namun, dalam hal ini kalimat di atas ditabukan pengucapannya karena dipercaya akan mendatangkan marabahaya terhadap apa yang dipuji. Bayi yang sedang sehat dan dipuji dipercaya akan menderita sakit.

(e) Menyombongan diri

(19) Nyan ata droe kuh mandum. (Itu punyaku semuanya)

Ujaran (19) di atas diucapkan seseorang dalam konteks memuji kelebihan terhadap apa yang ada pada dirinya. Dalam masyarakat Pidie ujaran demikian ditabukan karena dianggap sebagai perilaku sombong dan 'membelakangi' Yang Maha Kuasa sebagai pemilik segalanya di alam semesta ini. Sebagaimana diketahui bahwa segala yang ada di dunia ini adalah milik-Nya. Oleh sebab itu, perbuatan dan ucapan yang memuji dirinya atau apa yang dimilikinya secara berlebihan dilarang.

(f) Mengeluh

(20) Sakét sabé-sabé, han puléh-puléh lé sakét nyoe. (Sakit selalu, tidak sembuhsembuh lagi penyakit ini)

Seperti kalimat ujaran (20) di atas, seseorang dilarang mengeluh apabila sakit yang dideritanya tidak kunjung sembuh. Adanya larangan ujaran dalam konteks mengeluh pada kedua ujaran di atas sangat beralasan. Sebab, mengeluh secara berlebihan menyiratkan seolah-seolah seorang manusia tidak percaya lagi dengan ketetapan Tuhannya. Padahal, setiap apa yang terjadi terhadap makhluk di dunia ini adalah Tuhan yang mengatur semuanya dan manusia tidak boleh mengeluh dan berputus asa. Manusia dianjurkan agar terus berusaha dan berdoa agar kehidupan yang ia jalani mendapat rahmat dari Allah swt..

(g) Menantang

(21) Meunyôna kah inoe, kajak laju keunoe rimueng! (Kalau ada kamu di sini, datang saja ke sini harimau!)

Ujaran di atas ditabukan penggunaanya karena menantang terhadap sesuatu yang menghadirkan hal tidak baik. Menantang untuk bertemu dengan hantu dan menantang untuk bertemu dengan binatang buas, salah satu ujaran yang ditabukan. Sebab, masyarakat Pidie percaya, apabila menantang untuk hal yang tidak baik, suatu saat hal 


\section{Junaidi dan Vera Wardani, Konteks Penggunaan Bahasa Tabu .......}

yang tidak baik itu sewaktu-waktu akan hadir di hadapan mereka yang pernah menantangnya.

(h) Menghina

(22)Alahai klo, sapeu han deuh kadeungo. (Dasar tuli, apa pun tidak bisa kamu dengar)

Penggunaan kata klo pada ujaran di atas menjadi tabu jika diucapkan untuk menghina orang lain. Ujaran yang diucapkan untuk menghina dengan menggunakan setiap kekurangan yang dimilki orang lain ditabukan dalam masyarakat Pidie, karena masyarakat Pidie takut keadaan atas apa yang terjadi terhadap orang yang dihina itu sewaktu-waktu akan terjadi pada dirinya atau anggota keluarganya. Perlu diketahui bahwa ujaran seperti di atas tidak menjadi tabu apabila ujaran itu diucapkan dalam konteks bercanda dan hubungan antarpartisipan memiliki relasi yang sangat baik.

(i) Menyerang orang lain

Segala ujaran sumpah serapah yang diujarkan dalam konteks menyerang orang lain pada dasarnya sangat ditabukan dalam masyarakat Pidie. Segala bentuk sumpah serapah yang bertujuan menyerang orang lain seperti memarahi, memaki, menghujat, carut, dan menyindir dilarang karena dapat menyakiti orang lain. Selain itu, sumpah serapah tersebut juga dapat menimbulkan permusuhan antarsesama. Berikut adalah ujaran tabu dalam konteks memarahi orang lain yang ditabukan dalam masyarakat Pidie yang bertujuan untuk menyerang orang lain adalah sebagai berikut.

(23) E hai neuk sigeupap inoe! (Dasar anak kurang ajar!)

(24) Bit lagèe aneuk hana ma kah! (Seperti anak tidak ada ibu kamu!)

Data penggunaan bahasa tabu dalam masyarakat Pidie pada kalimat-kalimat ujaran di atas merupakan data-data yang mewakili kajian penelitian ini setiap aspeknya. Oleh sebab itu peneliti dalam artikel ini hanya menampilkan sampel data dari sekian banyak data sebagai pendukung kajian penelitian ini.

\section{PEMBAHASAN}

Pada dasarnya memang semua kata-kata dan ucapan yang ditabukan dalam masyarakat Pidie sangat dilarang dalam agama, yakni agama Islam sebagai agama yang mayoritas dianut oleh masyarakat Pidie. Selain itu itu, perlu diketahui bahwa secara ilmiah ujaran yang diucapkan dalam masyarakat Pidie akan menjadi bahasa tabu 
tergantung dalam konteks siapa, apa, bagaimana, di mana, dan kapan ujaran tersebut diujarkan. Hal ini sesuai pendapat Purwo (1990:21) yang menyatakan unsur-unsur konteks adalah siapa yang mengatakan kepada siapa, tempat, dan waktu diujarkannya suatu kalimat. Oleh sebab itu, ujaran yang dianggap tabu pada konteks tertentu belum tentu dapat menjadi tabu pada konteks lainnya.

Adapun salah satu cara yang dapat dilakukan untuk meminimalisir pengucapan secara langsung bahasa tabu, khususnya bahasa tabu kata-kata dalam kehidupannya, masyarakat dapat Pidie menggunakan bentuk eufemisme dalam pembicaraan sehari-hari. Hal tersebut sejalan dengan pendapat Kridalaksana (2008:59) yang menyatakan bahwa, eufemisme adalah pemakaian kata atau bentuk lain untuk menghindari bentuk larangan atau tabu. Kata-kata yang tabu dimaksud adalah kata yang dilarang dan dianggap kasar lalu digantikan dengan ungkapan yang lebih halus.

Di samping itu, pada bahasa tabu tertentu yang memang dilarang pengucapannya, masyarakat Pidie dapat menghindar dengan berbisik dan diam. Hal ini sejalan dengan pendapat Laksana (2009:65) yang menyatakan terdapat paling tidak tiga cara untuk menghindari pengucapan atau penyebutan tabu bahasa yaitu, (1) penutur dapat menghindar dengan diam; (2) penutur dapat menghindar dengan berbisik; dan (3) penutur dapat menghindar dengan menggantikan kata atau ungkapan tabu dengan kata atau ungkapan lain yang dilazimkan dalam masyarakat itu yang disebut eufemisme.

Tidak ada bentuk penyulihan kata apapun untuk menggantikan bahasa tabu sumpah serapah yang bertujuan menyerang orang lain secara verbal dalam masyarakat Pidie, selain penutur harus diam. Banyak bahasa tabu kata-kata yang beralih fungsinya menjadi bahasa tabu sumpah serapah yang diakibatkan oleh adanya tabu kata-kata yang digunakan pada tabu sumpah serapah yang bertujuan menyerang orang lain.

\section{KESIMPULAN}

Terdapat beberapa konteks penggunaan bahasa tabu dalam masyarakat Pidie. Konteks tersebut meliputi konteks, pembicara dan pendengar pembicaraan, latar atau tempat pembicaraan, waktu pembicaraan, topik atau peristiwa yang dibicarakan, suasana atau situasi pembicaraan, dan tujuan atau maksud pembicaraan. Adapun salah satu cara yang dapat dilakukan untuk meminimalisir pengucapan secara langsung bahasa tabu 
dalam kehidupannya khususnya bahasa tabu kata-kata, masyarakat Pidie menggunakan bentuk eufemisme. Namun, tidak ada bentuk penyulihan kata apapun untuk menggantikan bahasa tabu sumpah serapah yang bertujuan menyerang orang lain secara verbal, selain penutur harus diam dan menghindarinya.

\section{DAFTAR PUSTAKA}

- Abubakar, A., \& Anwar, A. (2018). Analisis Materi Pendidikan Berkarakter dalam Pembelajaran Sosiologi pada SMA Kota Banda Aceh. Jurnal Serambi Ilmu, 22(1), 164-173.

- Abubakar, A., Srimulyani, E., \& Anwar, A. (2019). Identification of Some Distinctive Values of Acehnese Malee (Shyness) for Character Education. Jurnal Ilmiah Peuradeun, 7(1), 125-140.

- Bakar, Aboe. dkk. (1985). Kamus Aceh Indonesia. Jakarta: PPPB Depdikbud.

- Brown dan George Yule. (1983). Discourse. Cambridge: University Press.

- Chaer, Abdul dan Leonie Agustina. (2010). Sosiolinguistik; Perkenalan Awal. Jakarta: Rineka Cipta.

- Halliday, M.A.K dan Ruqaiya Hasan. (1985). Bahasa Konteks dan Teks: Aspek- Aspek Bahasa dalam Pandangan Semiotik Sosial. Diterjemahkan oleh Asruddin Barori Tou. 1994. Yogyakarta: UGM Press.

- Hasan, M. Iqbal. (2002). Pokok-pokok Materi Metodologi Penelitian dan Aplikasinya. Jakarta: Ghalia Indonesia.

- Israwati, I. (2018). Pengaruh Strategi Pembelajaran dan Motivasi Mengajar Guru Terhadap Hasil Belajar Siswa. Jurnal Serambi Ilmu, 19(2), 65-124.

- Kridalaksana, Harimurti. (2008). Kamus Linguistik. Jakarta: Gramedia Pustaka Utama.

- Laksana, I Ketut Darma. (2009). Tabu Bahasa: Salah Satu Cara Memahami Kebudayaan Bali. Denpasar: Udayana University Press.

- Moeliono, Anton M. (1991). Santun Bahasa. Jakarta: Gramedia Pustaka Utama.

- Nazir, Moh. (2005). Metodologi Penelitian. Bogor: Ghalia Indonesia.

- Ohoiwutun, Paul. (2007). Sosiolinguistik; Memahami Bahasa dalam Konteks Masyarakat dan Kebudayaan. Jakarta: Visipro. 
- Purwo, Bambang Kaswati. (1990). Pragmatik dan Pengajaran Bahasa. Yogyakarta: Kanisius.

- Pusat Bahasa. (2008). Kamus Besar Bahasa Indonesia (Edisi Ketiga). Jakarta: Gramedia Pustaka Utama.

- Rahardi, R. Kunjana. (2005). Pragmatik: Kesantunan Imperatif Berbahasa Indonesia. Jakarta: Erlangga.

- Razali, R., \& Ibrahim, I. (2017). Aceh Language Learning Implementation In Smp Negeri Kota Banda Aceh. Jurnal Serambi Ilmu, 29(2).

- Samarin, W.J. (1988). Ilmu Bahasa Lapangan. Yogyakarta: Kanisius.

- Sumarsono dan Paina Partana. (2004). Sosiolinguistik. Yogyakarta: Sabda.

- Sutarman. (2013). Tabu Bahasa dan Eufemisme. Surakarta: Yuma Pustaka. 